Portland State University

PDXScholar

\title{
Overlooked Density: Re-Thinking Transportation Options in Suburbia, Phase II
}

Nico Larco

University of Oregon

Follow this and additional works at: https://pdxscholar.library.pdx.edu/trec_reports

Part of the Transportation Commons, Urban Studies Commons, and the Urban Studies and Planning Commons

Let us know how access to this document benefits you.

\section{Recommended Citation}

Larco, Nico. Overlooked Density: Re-Thinking Transportation Options in Suburbia, Phase II. OTRECRR-11-15. Portland, OR: Transportation Research and Education Center (TREC), 2011. https://doi.org/ 10.15760/trec.36

This Report is brought to you for free and open access. It has been accepted for inclusion in TREC Final Reports by an authorized administrator of PDXScholar. Please contact us if we can make this document more accessible: pdxscholar@pdx.edu. 


\title{
SOTREC
}

FINAL REPORT

\author{
Overlooked Density: \\ Re-Thinking Transportation \\ Options in Suburbia, Phase II
}

OTREC-RR-11-15

March 2011 



\title{
OVERLOOKED DENSITY: RE-THINKING TRANSPORTATION OPTIONS IN SUBURBIA, PHASE II
}

\author{
Final Report \\ OTREC-RR-11-15 \\ by \\ Nico Larco, AIA \\ University of Oregon
}

for

Oregon Transportation Research and Education Consortium (OTREC)

P.O. Box 751

Portland, OR 97207

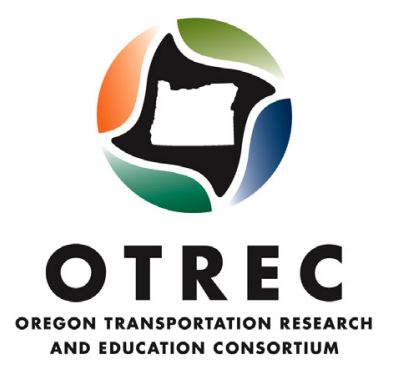

March 2011 



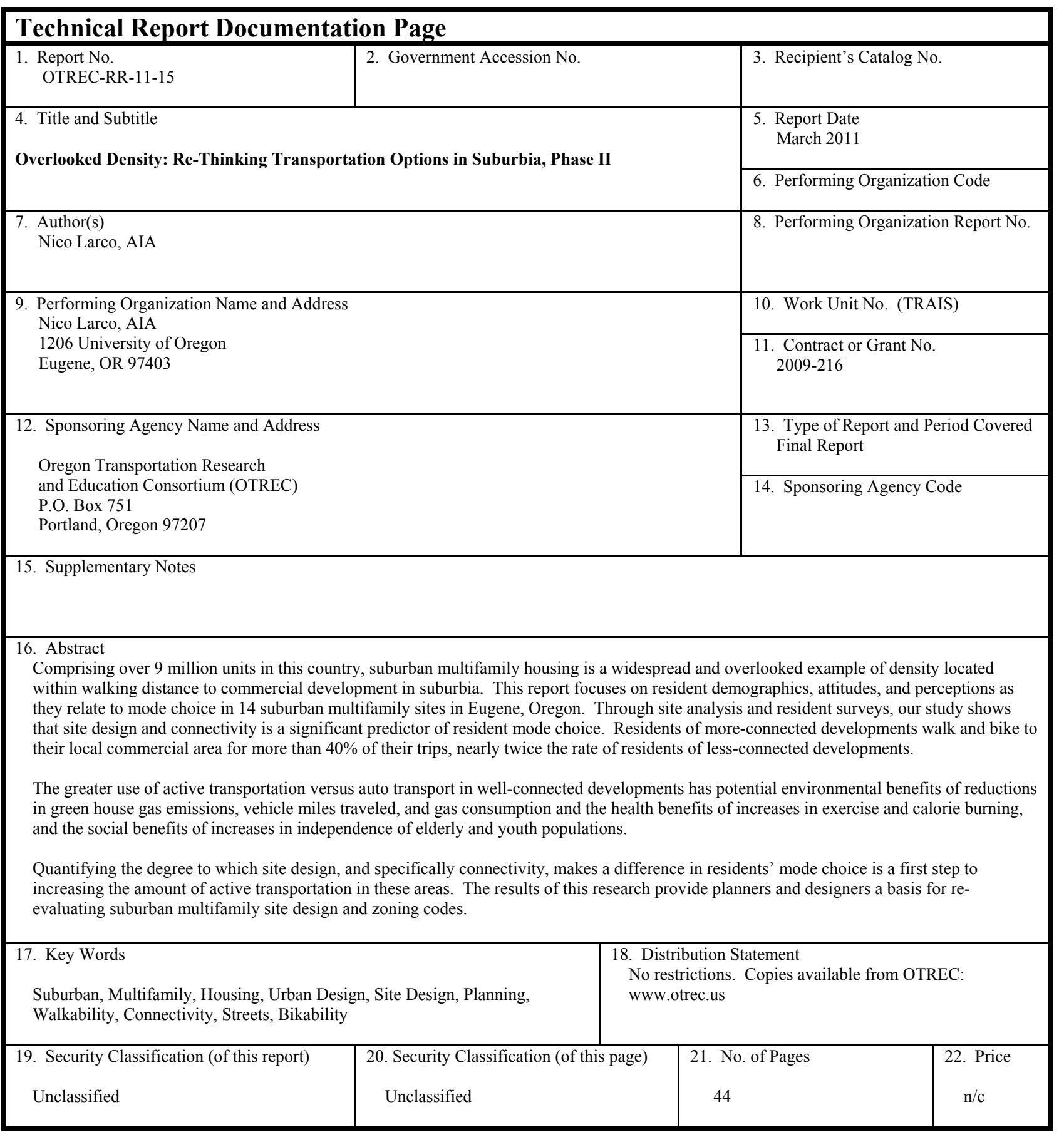




\section{ACKNOWLEDGEMENTS}

I would like to thank the Oregon Transportation Research and Education Consortium for funding this project. I would also like to thank the students and staff of the Community Planning Workshop (CPW), who eagerly researched multifamily housing and pedestrian connectivity and worked hard to create the project deliverables. From CPW, I would specifically like to thank Robert Parker (CPW Director), Bethany Steiner (CPW Associate Director), Amanda West (Program Coordinator), Barry Gordon, Kevin Bellanger, Emma Pachuta, and Becky Rottenstein. Kevin deserves particular thanks for his diligent assistance in creating this report. I would also like to thank Kristin Kelsey, as she has played an instrumental role throughout this entire project.

\section{DISCLAIMER}

The contents of this report reflect the views of the authors, who are solely responsible for the facts and the accuracy of the material and information presented herein. This document is disseminated under the sponsorship of the U.S. Department of Transportation University Transportation Centers Program in the interest of information exchange. The U.S. Government assumes no liability for the contents or use thereof. The contents do not necessarily reflect the

official views of the U.S. Government. This report does not constitute a standard, specification, or regulation. 


\section{TABLE OF CONTENTS}

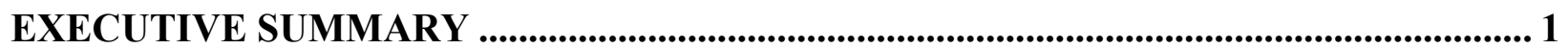

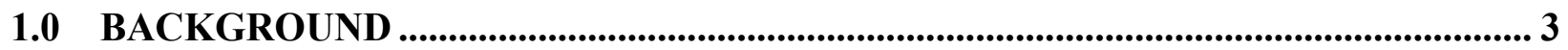

2.0 THE LINK BETWEEN SUBURBAN MULTIFAMILY HOUSING AND

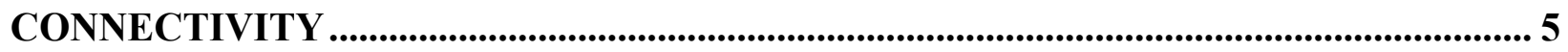

2.1 WHAT IS SUBURBAN MULTIFAMILY HOUSING? ………………………........... 5

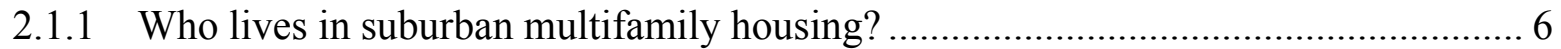

2.2 WHAT IS CONNECTIVITY? ........................................................................... 7

2.3 MULTIFAMILY HOUSING AND CONNECTIVITY ............................................ 7

2.3.1 Health, Economics and Equity ......................................................................... 8

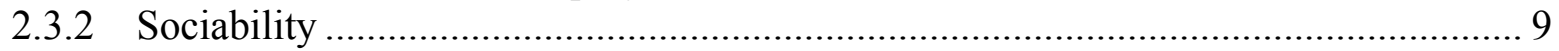

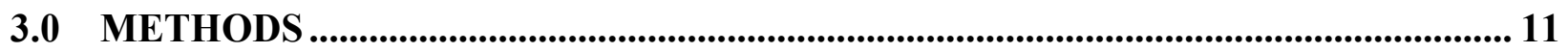

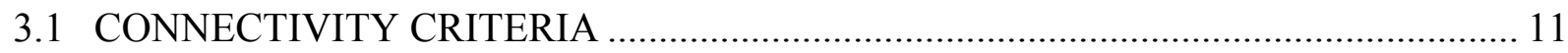

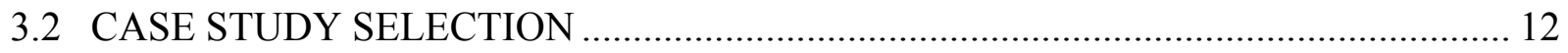

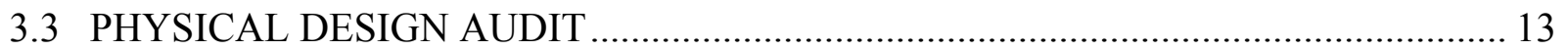

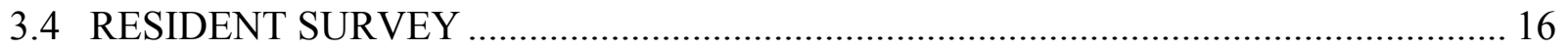

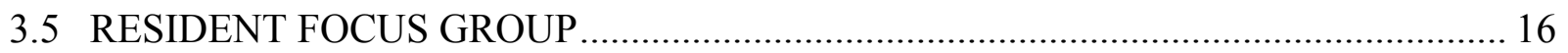

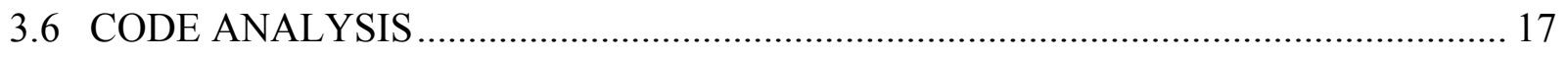

3.7 PLANNER/DEVELOPER FOCUS GROUP ………................................................. 17

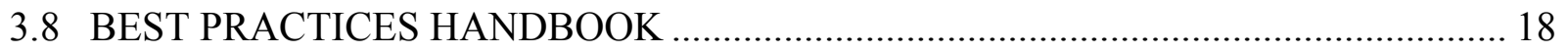

4.0 FINDINGS \& RECOMMENDATIONS..................................................................... 19

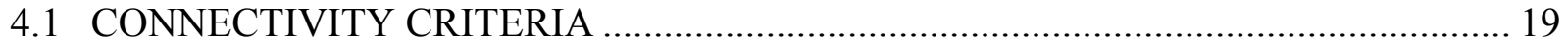

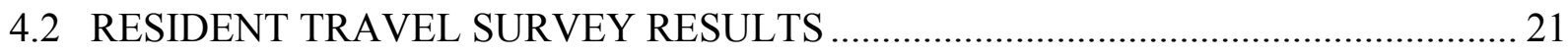

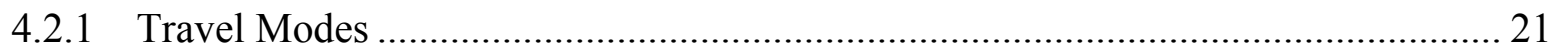

4.2.2 Factors Influencing Transportation Choices ............................................................. 22

4.2.3 Ease of Walking and Biking …………............................................................. 24

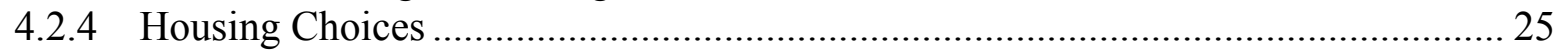

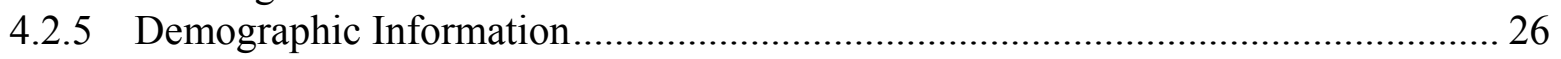

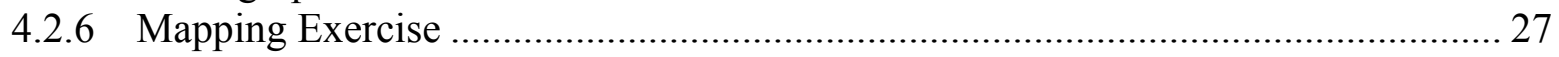

4.2.7 Resident Focus Group ............................................................................... 28

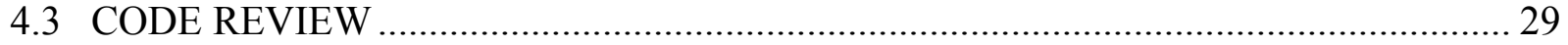

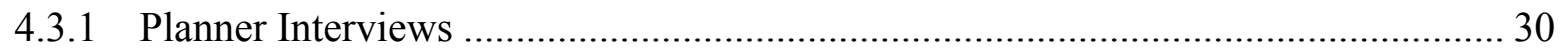

4.3.2 Eugene Planner/Developer Focus Group ............................................................. 30

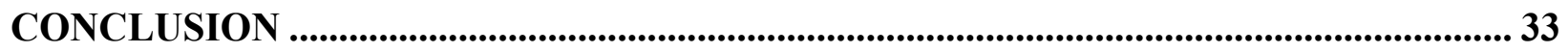

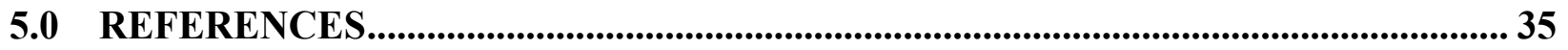




\section{LIST OF TABLES}

Table 2.1: Eugene Multifamily Housing Resident Characteristics................................................ 6

Table 3.1: Connectivity Measurement Criteria........................................................................ 12

Table 3.2: Characteristics of Case-Study Multifamily Housing Developments, Eugene, Ore ..... 14

Table 3.2: Ten Principles for Well-Connected Multifamily Developments.................................. 18

Table 4.1: Case-Study Sites after Using the Connectivity Criteria ............................................... 19

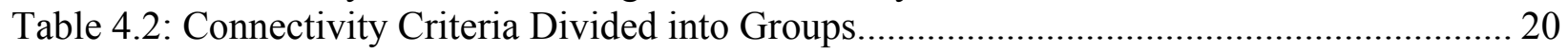

Table 4.3: Percent of Trips Per Week by Travel Mode ............................................................... 21

Table 4.4: Travel Mode by Site Connectivity............................................................................. 22

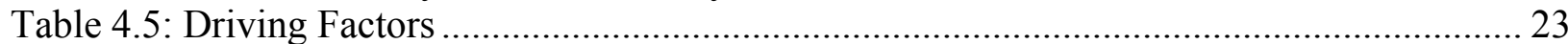

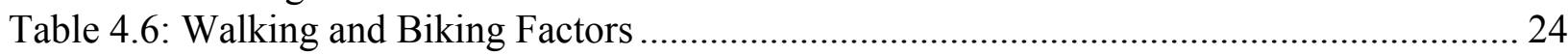

Table 4.7: Perception of Ease of Walking and Biking.............................................................. 25

Table 4.8: Would you walk or bike more if it were made easier or more convenient to do so? .. 25

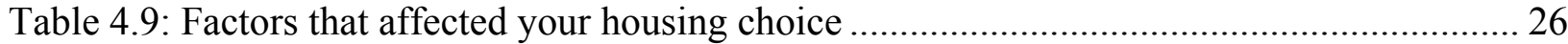

Table 4.10: Demographic Characteristics of Residents ............................................................... 26

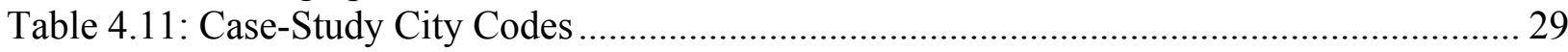

Table 4.12: Elements that Might Influence the Level of Connectivity in Multifamily

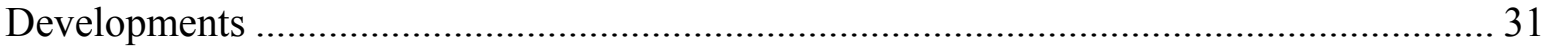

\section{LIST OF FIGURES}

Figure 2.1: Large parking lot, Salem, Ore ......................................................... 5

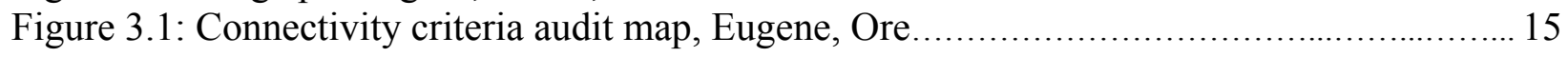

Figure 3.2: Protected pedestrian path, Corvallis, Ore .............................................. 18

Figure 3.3: Unprotected pedestrian path, Salem, Ore ............................................... 18 


\section{EXECUTIVE SUMMARY}

Suburban multifamily housing is the fastest growing housing type in the United States. An estimated nine million multifamily housing units already exist in suburbs and another five million are projected to be built within 20 years. Suburban multifamily housing is unique in comparison to multifamily housing in urban areas as suburban developments are often only accessible by automobile.

Suburban multifamily housing often sits as a transition between single-family housing and commercial areas. Multifamily residents are often adjacent to or near local commercial areas (LCAs), but because of current site designs, pedestrian paths tend to be difficult to access. By creating better connected developments, walking and biking are made easier for residents of multifamily housing. This has the potential to save residents money, provide environmental benefits, and increase residents' health and sociability.

This study explores pedestrian connectivity in suburban multifamily housing and investigates the link between mode choice and connectivity in these developments. The study team created a set of connectivity criteria; administered a resident travel survey; held interviews and focus groups of both residents and planning and developing professionals; and performed a case-study code analysis to examine the current state of pedestrian connectivity in suburban multifamily housing and explore ways to improve it in future developments.

Survey data indicates that there is a significant difference between the travel behaviors of residents in well-connected versus less-connected developments. A greater percentage of residents of well-connected developments "ever walk or bike" to their LCA (73\%) than residents of less-connected developments $(58 \%)$. In addition, walking trips to the LCA are nearly twice the percentage of total trips in well-connected developments (43.0\%) versus less-connected developments (23.7\%). Dispelling commonly held beliefs about the amount of walking and biking occurring in suburbia, our study shows that more than a third of all trips to the LCA by residents of both groups are active travel trips.

Through the code review process, it was also determined that the codes of cities with wellconnected pedestrian networks share many of the same elements including: mandated sidewalks, bicycle parking, open space and street-landscaping requirements. Planners noted that politics often create a misunderstanding between planners and developers in creating well-connected developments, and provided examples of how some cities work beyond these politics.

Future studies should focus on larger analyses of pedestrian travel habits to better compare residents of urban and suburban areas, as well as a greater analysis of the connectivity criteria. Focus should also be placed on how to retrofit existing developments for better connectivity. 


\subsection{BACKGROUND}

The suburbs hold a special place in American culture. People have sought out a home on a quiet suburban street for decades, touting the perceived privacy, safety and cleanliness of the suburbs as compared to the city. The American road systems, most notably highways, were created with suburban transportation in mind, allowing residents to commute from their home in the suburbs to their job in the city and back home using their automobiles, which became symbols of status and independence.

This suburban ideal has been contested recently, most notably by those concerned with transportation and its environmental impacts. By creating roads that are designed to maximize efficiency with widths that can accommodate traffic during peak hours, transportation planners have made driving the default for travel. In suburbia, desired destinations are often too far away to walk, bike or use public transit. When amenities are reasonably close, they are often difficult to access by pedestrians because of dangerous roads, a lack of pedestrian infrastructure, and indirect routes. Related to this, an increase in driving, with the decrease in walking and biking, also has been implicated in the nation's obesity epidemic.

Previous research has explored ways to increase walking and biking through the ideas of walkability (encouraging physical activity with pedestrian infrastructure and destinations that are close together and barrier-free) and pedestrian connectivity (which explores the types and directness of pedestrian routes between two points). Several studies have been conducted on pedestrian travel routes and behaviors, most notably in urban or transit-oriented settings (Agrawal et al. 2008, Handy et al. 2003, Hess et al. 1999). While there has been some inclusion of suburban neighborhoods in these studies, there has been a lack of discussion about multifamily housing in suburbia. Suburban multifamily housing is the fastest growing segment of the U.S. housing stock, and continues to grow each year, even in times of economic turmoil (U.S. Census Bureau, 2007).

Multifamily housing is unique in suburbia in that it is high-density development typically located close to commercial areas, and often acts as a buffer between these commercial areas and singlefamily housing. While the proximity of medium to high residential density (up to 30 units/acre) and commercial destinations exists, the lack of pedestrian connections between multifamily housing and commercial areas is limiting potential active travel and the ecological, economic and social advantages that can come with it.

This research focuses on understanding the degree to which connectivity has an effect on mode choice for suburban multifamily housing residents. This report is organized into the following sections: definitions of multifamily housing and connectivity; project methodology; findings and recommendations; and conclusions for future multifamily housing developments. 


\subsection{THE LINK BETWEEN SUBURBAN MULTIFAMILY HOUSING AND CONNECTIVITY}

\subsection{WHAT IS SUBURBAN MULTIFAMILY HOUSING?}

Suburban housing is often considered to be comprised solely of low-density, detached, singlefamily homes. However, almost one in four housing units in suburbia is an alternative to singlefamily housing, with most of these units actually being medium- to high-density (12-30 units per acre) multifamily housing (Larco 2009). There are more than nine million multifamily housing units in suburbia (AHS 2007) and another five million units are projected to be built in the next 20 years. In addition, suburban multifamily housing has been the fastest growing segment of the housing market since 1970, far outpacing single-family homes.

Suburban multifamily housing is different than multifamily housing found in urban areas in that they are often on large lots (often over three acres), include multiple buildings, and often have their own internal circulation infrastructure. Buildings tend to be two or three stories in height with double-loaded corridors, wood-frame construction, exterior vertical circulation, and balconies. Parking is often exterior to the building, taking up most of the space around buildings (see Figure 2.1). Many developments have assigned parking spaces, with one or more spaces per unit.

Figure 2.1: Large parking lot, Salem, Ore.

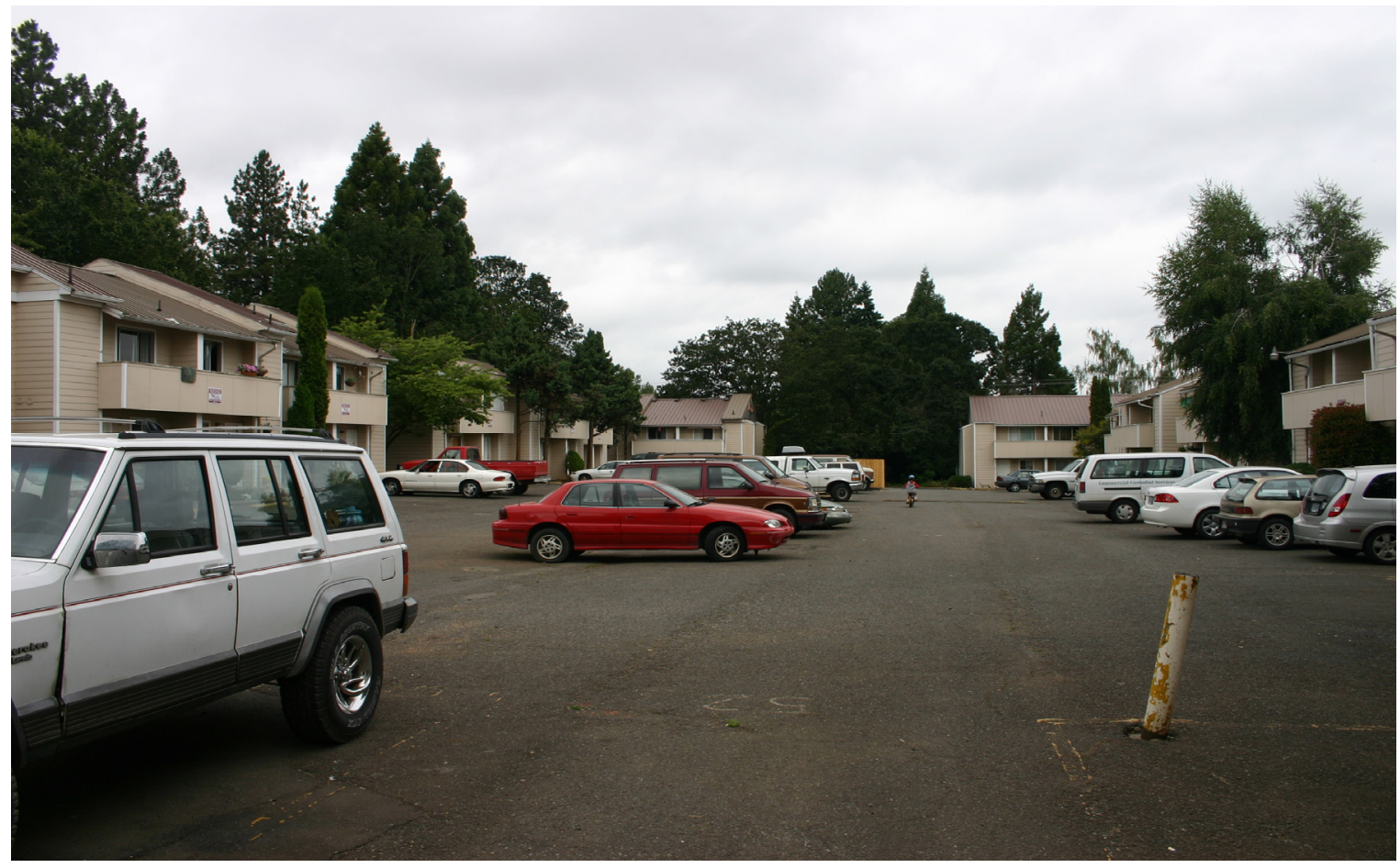


Suburban multifamily housing is often located along major arterial roads and is used as a buffer between commercial areas and single-family housing. These arterial roads provide "perhaps the least hospitable pedestrian path... [with] few, if any, designated crosswalks and [are] much too wide for a pedestrian to cross safely" (Southworth 2005). While these developments tend to be connected to arterials, because of a lack of pedestrian and bicycle infrastructure and connectivity they are not typically easily accessible to each other or to nearby commercial areas by walking or biking.

\subsubsection{Who lives in suburban multifamily housing?}

A broad spectrum of individuals live in suburban multifamily housing. Many of the residents are drawn to the suburbs due to the amenities or proximity to employment, but desire the increased mobility and decreased maintenance and cost of multifamily housing compared to single-family housing. While single-family housing is made up of primarily nuclear families, nationally about two-thirds of households in suburban multifamily housing are what the U.S. Census defines as "non-families." This is defined as individuals living alone or with roommates, divorcees, widows and unmarried couples. Suburban multifamily housing is also more ethnically and racially diverse than single-family housing (Larco 2010).

Table 2.1: Eugene Multifamily Housing Resident Characteristics (shown as percentages)

\begin{tabular}{l|c|c}
\hline Household Income & $\begin{array}{c}\text { 2009 Eugene Multifamily } \\
\text { Housing Survey }\end{array}$ & $\begin{array}{c}\text { 2007 Eugene } \\
\text { Census }\end{array}$ \\
\hline$<\$ 30,000 /$ year & 56.6 & 34.1 \\
\hline$>\$ 90,000 /$ year & 1.5 & 16.1 \\
\hline Household Type & & 34.0 \\
\hline Single w/o children & 37.1 & 8.2 \\
\hline Single w/ children & 16.1 & 16.0 \\
\hline Married/partner w/ children & 17.7 & 23.9 \\
\hline Married/partner w/o children & 16.9 & 82.3 \\
\hline Race & & 1.5 \\
\hline White & 82.8 & 5.7 \\
\hline Black & 3.0 & 1.4 \\
\hline Asian & 1.0 & 7.1 \\
\hline American Indian/Alaskan Native & 5.1 & 0.1 \\
\hline Hispanic & 2.0 & \\
\hline Native Hawaiian/Pacific Islander & 1.5 & \\
\hline
\end{tabular}

Source: CPW Multifamily Travel Survey, 2009; American Community Survey, U.S. Census

Table 2.1 shows the demographics of residents of the multifamily housing study sites in Eugene, Ore. (determined by our survey of multifamily housing residents in 2009) and the Eugene population as a whole (determined by the American Community Survey of 2007). Over half of our study residents make less than $\$ 30,000$ per year, a higher percentage than the 2007 Eugene Census, but mostly attributable to the fact that a number of study sites were specifically low- 
income housing developments. It is critical to note that nearly half of the residents earn between $\$ 30,000$ and $\$ 90,000$ and that some residents actually earn more than $\$ 90,000$. Consistent with national data (ACS, 2007), this shows that suburban multifamily housing is a housing choice for a wide range of income earners and is not solely low-income housing.

In regards to household type, survey resident are primarily single without children. Also consistent with Eugene in general, surveyed residents are also primarily white but also include a range of minority groups.

\subsection{WHAT IS CONNECTIVITY?}

Connectivity, for the purposes of this study, is a measure of the amount and types of designed pedestrian routes within an area, including sidewalks and pedestrian paths. These routes connect residents to the buildings and amenities inside their complex as well as the larger neighborhood. Typically, higher connectivity correlates to less difference between the "as the crow flies" distance and the walking distance between two points. This is especially significant in suburbia since street patterns are fragmented in many suburban neighborhoods, causing walking distances to often be significantly longer than the straight-line distance (Southworth 2005, Frank et al. 2003). The degree of path continuity and the absence of barriers also play an important role in creating a well-connected pedestrian network.

While researchers have started to develop ways to measure connectivity, existing literature typically does not differentiate between pedestrian networks and street networks when discussing connectivity, as sidewalks are typically considered to be located along streets. Handy et al. (2003) discusses several measurements, including a Connectivity Index, which calculates the number of street links divided by the number of nodes or link ends. That report also discusses a measure comprised of the ratio between the travel distances between two points using the pedestrian-dedicated network divided by the straight-line distance between the points. Overall, both of these measures gauge the directness of paths between destinations. The first is a rough measure of all potential origins and destinations (a network score) and the second is a specific path-based measure (a path score).

In this study, we started with these widely used measures of general connectivity evaluation, but also developed an additional set of connectivity measures that specifically address the unique conditions of large-lot multifamily development (i.e., developments where the pedestrian network is not necessarily associated with a street network). This led to the "Connectivity Criteria," which are outlined in Section 3.1.

\subsection{MULTIFAMILY HOUSING AND CONNECTIVITY}

Currently, suburban pedestrian travel routes are not direct. A study by Hess et al. (1999) showed that "on average, the length of walking routes is 27 percent longer than the air lines distance between residential and commercial areas in urban sites, versus 66 percent in suburban sites." This discrepancy between urban versus suburban sites can be largely attributed to typically 
disconnected street patterns in suburbia that include cul-de-sacs, looped roads, and limited access between neighboring developments.

This disconnected nature of suburban development can act as a barrier to active travel as actual travel distance to destinations is further. While this is often not seen as critical in suburbia, a location where active travel is typically not considered, researchers have observed that the proximity of suburban shopping centers and suburban multifamily housing could play a significant role in the future of suburban transportation planning (Larco 2009, Hess et al. 1999). This has led to the recommendation that "the sheer number of people living in these neighborhoods (typically in multifamily developments) also calls for further research on the potential of these areas to contribute to a balanced transportation program" (Hess et al. 1999).

The latent potential in proximity of residences and commercial areas can reduce residents' reliance on automobiles and increase active modes of travel such as walking and biking, especially for short trips under a half mile. Increasing active travel might reduce vehicle miles traveled, which has positive impacts on the environment as it reduces carbon emissions. In addition, walking and biking can have a positive effect on residents' physical and mental health and can provide economic savings.

Residents of multifamily housing are an ideal demographic to make utilitarian, non-work-related, active travel trips as they have already been reported to use active travel significantly more than single-family residents for work-related trips. In 2005, the U.S. Census Bureau reported that multifamily residents are three times more likely than single-family residents to walk or bike to work, four times more likely to use transit, and twice as likely to carpool (U.S. Census, American Housing Survey, 2005). Since multifamily housing is often used as a buffer around commercial development, suburban multifamily residents are often living within walking distance to commercial areas.

\subsubsection{Health, Economics and Equity}

Recent research has established a strong link between health benefits and environments that support active travel (Frank and Engelke 2005; Frank and Kavage 2008). Health benefits include a reduction in obesity rates, mortality rates and rates of illness, and also have been correlated with increased productivity (seen as a reduction of sick days). In addition to these benefits, active travel also can increase quality of life by increasing the independence of individuals who would otherwise have to rely on auto transport. This is important for populations who have limited access to cars due to costs or being too young or too elderly to drive. This is especially critical for suburban multifamily housing as the typical demographic of this housing type includes the elderly, economically disadvantaged individuals and, to a lesser extent, youth (Larco 2010). While multifamily housing attracts residents with a wide income range, this range does include a substantial proportion of individuals who are economically challenged and are living in multifamily housing because it is an affordable option that tends to be close to workplaces and commercial areas. Increasing active travel for these populations can have an economic effect as residents do not need to have access to automobiles or pay for additional fuel for these short trips. 


\subsubsection{Sociability}

Walking is also a form of community building that has suffered from the need for personal automobile transportation. Freeman (2001) noted that "the sprawling neighborhoods of today are thought by many to spawn social isolation in their inhabitants."

There is a level of healthy community interaction which comes from casual interaction on streets with pedestrian and transit systems, creating "social capital" in the social networks and interactions that inspire trust among neighbors (Newman and Kenworthy 1999, Leyden 2003). A study in Galway, Ireland, a growing suburb, suggests that residents of more walkable neighborhoods have higher levels of social capital, communicate more with their neighbors and are more socially engaged (Leyden 2003). Creating areas that promote active travel in suburban multifamily developments can potentially foster this increase in social capital. 


\subsection{METHODS}

To develop the criteria for pedestrian connectivity as well as how residents of multifamily housing make their travel decisions, this study used a mixture of quantitative and qualitative information gathering. These methods included surveys, interviews, focus groups and case studies. It was important to gather quantitative information to develop a baseline of actual resident mode choice and attitudes. It was equally important to speak with both residents and professionals to gather qualitative information about their perceptions of active travel related to suburban multifamily housing.

Information throughout this study was presented to staff at the City of Eugene, the Oregon Department of Transportation (ODOT), and the Oregon Department of Land Conservation and Development (DLCD), who all gave invaluable input throughout the process.

\subsection{CONNECTIVITY CRITERIA}

The initial step of this study was to identify connectivity measures to develop criteria that could be used to systematically evaluate the pedestrian and bicycle connectivity of suburban multifamily developments. For the purposes of this study, we sought to identify elements that create well-connected environments and those that create less-connected environments.

Previous research related to connectivity has been primarily focused on urban settings with a secondary focus on suburban neighborhoods (Handy et al 2003, Frank et al. 2003, Southworth 2005). This previous research provides an overview of the concept of connectivity and generic travel habits; however, information gathered from that research was not sufficient for the needs of this study as our target areas where qualitatively different than the areas investigated in those studies. This study focuses on suburban multifamily housing, which is different than most typologies in urban and suburban settings in that these developments have large lots that are often without any internal street network. Instead, vehicular circulation is contained in large parking lots or parking lanes (vehicular lane with perpendicular parking on both sides) and the pedestrian network is often distinct from the vehicular circulation path. Also, pedestrian paths (both formal and informal) often connect directly with adjacent developments, regardless of vehicle connections.

The connectivity measurement criteria, outlined in Table 3.1, are divided into three types of measurements. The first type of criteria, Internal Connectivity, measures connectivity within multifamily developments, most notably how residents get from their buildings to destinations internal to the development as well as to exits and entrances to the development itself. Important criteria in this category include pedestrian route directness, which measures the distance between two destinations along the pedestrian-dedicated route and the straight-line distance, and development network node density, which measures the amount of pedestrian options inside a development by the number of sidewalk intersection points. Both of these measures are similar 
to typical connectivity criteria with the slight difference that they focus on the pedestrian networks instead of street networks. Another important criterion is the pedestrian friendliness of the automobile realm, which is measured by looking at the types of vehicular paths and parking areas (parking lots, parking lanes, parking pods, etc.) and comparing them in terms of their compatibility with pedestrian travel.

Table 3.1: Connectivity Measurement Criteria

\begin{tabular}{l|l}
\hline Type of Connectivity & Measurement \\
\hline \multirow{4}{*}{ Internal } & 1. Presence of Continuous Pedestrian Circulation Network: Building to Building \\
\cline { 2 - 2 } & $\begin{array}{l}\text { 2. Presence of Continuous Pedestrian Network: Internal Network to the } \\
\text { Development Egress Point }\end{array}$ \\
\cline { 2 - 2 } & 3. Pedestrian Network Node Density \\
\cline { 2 - 2 } & 4. Pedestrian Route Directness \\
\cline { 2 - 2 } & 5. Pedestrian Friendliness of the Automobile Realm \\
\hline Pass-Through & 6. Access Point Distribution \\
\hline External & 7. External Route Directness \\
\cline { 2 - 2 } & 8. Presence of Protected Pedestrian Path \\
\cline { 2 - 2 } & 9. External Street Type \\
\hline
\end{tabular}

The second type of criteria, Pass-Through Connectivity, explores how people from inside and outside of the development can get through the development to access adjacent properties. There is only one criterion for pass-through connectivity, which is access point distribution. Access point distribution measures the angles between access points in a development. Multiple, welldistributed access points will result in smaller angles, which lead to a greater amount of choices to get in and out of a development and less "access shadows" or areas that are inaccessible by residents.

External Connectivity, the third type of criteria, measures the ease with which residents can get from their development to a commercial area. Important criteria in this category include external route directness, which is the difference between the straight-line distance between a building and a commercial area and the actual network distance, as well as presence of a protected pedestrian path, which gives a ratio of how much of a pedestrian path is along a pedestrian protected route with sidewalks, trees lining the street and other protective elements.

These criteria were used to evaluate potential case-study sites and allowed us to designate these developments as either well-connected or less-connected. Top researchers in the field of pedestrian transportation and connectivity as well as professionals across the state of Oregon provided feedback on these criteria and helped to narrow ideas to the current list. The full connectivity index is available from the authors.

\subsection{CASE STUDY SELECTION}

For this study, we focused on sites around Eugene, Ore., a mid-sized city (155,000 residents) in western Oregon located at the southern end of the Willamette Valley. Eugene has a substantial suburban area around the city center; has a typical amount of suburban multifamily housing development for a city of its size; and allows a natural experiment related to differences in connectivity as it changed its multifamily zoning code to mandate increased connectivity in 
2001. This code change included changes to the street network requirements, parking design and pedestrian infrastructure.

To select the potential case-study sites, we used geographic information systems (GIS), countylevel tax parcel data that contained land-use descriptions, site addresses and parcel sizes. An initial "potential site list" of a few dozen developments in Eugene fit the criteria of suburban location, multifamily housing land-use designation, a minimum of 30 housing units in the development, and larger than two acres. The lower limit on unit numbers and acreage was used to eliminate developments that were not large enough to need their own internal circulation infrastructure.

Since the purpose of this study was to analyze people's travel routes, it was necessary to have a standard destination for each development. This study employed the concept of "pedestrian magnets" to be the qualifying criteria for destinations and referred to the description provided by the U.S. Green Building Council's Leadership in Energy and Environmental Design (LEED). According to LEED's 2005 publication, "Development Density and Community Connectivity," commercial pedestrian magnets include destinations such as banks, grocery stores, post offices, restaurants and commercial offices. For our study, all case-study sites were within walking distance $(1 / 4$ mile) of a commercial magnet that had to include a grocery store. Grocery stores were selected as a "minimum" criteria, as they are ubiquitous and are often daily, utility-based destinations.

\subsection{PHYSICAL DESIGN AUDIT}

From the list of potential sites within a quarter-mile of a grocery store, we selected 14 developments that represented a range of connectivity and were comparable (between the connectivity groupings) in terms of ranges of size, density, proximity to commercial areas, and quantity and quality of commercial development nearby. To arrive at the connectivity ratings, we completed a physical audit of the final 14 case-study sites using the connectivity criteria discussed in Section 3.1. For each study site, we generated a numeric score for each connectivity measure and then ranked the site relative to the other sites in the study. To create a composite measure we compiled these individual scores and created an overall connectivity score for each site. These connectivity scores ranged from 0 (poorly connected) to 100 (very well connected). It is important to note that because the connectivity score was based on rankings between the casestudy sites, the absolute score is only useful as a relative measure of connectivity and not an absolute measure that can be used with sites outside of this study.

The differentiation between well-connected and less-connected developments was established at a natural break in the continuum of connectivity and was then verified via discussions with landuse and transportation planners and professionals. Table 3.2 shows the characteristics of the 14 case-study development sites. While individual sites varied in respect to the controlled variables, this variation was similar across the two groups (well-connected and less-connected) and both groups had similar averages in each category. The one discrepancy within the groups was in the number of commercial establishments in the local commercial area (LCA), with well-connected developments having fewer establishments than less-connected developments. As our hypothesis was that well-connected developments would actually have more pedestrian activity 
regardless of having less stores available (i.e., the connectivity was the critical variable, not the number of stores) we were not concerned by this discrepancy.

Table 3.2: Characteristics of Case-Study Multifamily Housing Developments, Eugene, Ore.

\begin{tabular}{|c|c|c|c|c|c|c|c|c|c|}
\hline $\begin{array}{l}\text { Development } \\
\text { Name }\end{array}$ & $\begin{array}{l}\text { Connect } \\
\text {-ivity } \\
\text { Score } \\
\end{array}$ & $\begin{array}{l}\text { Size } \\
\text { (acres) }\end{array}$ & $\begin{array}{l}\text { Total } \\
\text { Units }\end{array}$ & $\begin{array}{l}\begin{array}{l}\text { Density } \\
\text { (total }\end{array} \\
\text { units/acre) }\end{array}$ & $\begin{array}{l}\text { Straight } \\
\text { Line } \\
\text { Distance } \\
\text { to LCA } \\
\text { (feet) } \\
\end{array}$ & $\begin{array}{l}\text { Network } \\
\text { Distance } \\
\text { to LCA } \\
\text { (feet) }\end{array}$ & $\begin{array}{c}\text { \# of } \\
\text { Comm. } \\
\text { Establis } \\
\text { hments } \\
\text { in LCA } \\
\end{array}$ & $\begin{array}{l}\text { LCA } \\
\text { Size } \\
\text { (acres) } \\
\end{array}$ & $\begin{array}{l}\text { Walk } \\
\text { Score } \\
\text { TM } \\
\end{array}$ \\
\hline \multicolumn{10}{|l|}{ Well-Connected } \\
\hline Heron Meadows & 74 & 16.02 & 300 & 18.73 & 810.0 & 971.0 & 16 & 11.27 & 60 \\
\hline The Crossings & 69 & 5.94 & 208 & 17.24 & 575.9 & 819.6 & 27 & 22.06 & 52 \\
\hline Parkside Apt. & 61 & 14.17 & 254 & 17.92 & 1322.6 & 1470.9 & 27 & 22.06 & 54 \\
\hline Sheldon Village & 48 & 3.05 & 73 & 23.96 & 402.5 & 516.6 & 38 & 17.5 & 74 \\
\hline Green Leaf Vlge & 46 & 2.02 & 36 & 17.79 & 793.8 & 2799.0 & 60 & 32.67 & 66 \\
\hline Apple Orchard & 44 & 2.21 & 40 & 18.13 & 661.2 & 2763.4 & 60 & 32.67 & 69 \\
\hline Average & 57 & 7.24 & 151.83 & 18.96 & 761.0 & 1556.8 & $35.25 *$ & $20.88^{*}$ & 62.50 \\
\hline \multicolumn{10}{|l|}{ Less-Connected } \\
\hline Santa Clara Place & 34 & 3.05 & 60 & 19.68 & 1214.2 & 1405.2 & 49 & 31.51 & 72 \\
\hline Woodland Creek & 30 & 5.91 & 58 & 9.82 & 1210.7 & 2185.3 & 160 & 76.21 & 82 \\
\hline Oak Meadow & 27 & 8.72 & 120 & 13.76 & 1304.8 & 2280.9 & 160 & 76.21 & 78 \\
\hline Oak Lane & 27 & 3.4 & 129 & 37.97 & 1556.5 & 2103.0 & 160 & 76.21 & 78 \\
\hline Riviera Village & 23 & 13.97 & 162 & 11.6 & 672.5 & 1206.7 & 31 & 7.23 & 63 \\
\hline Applewood & 22 & 5.36 & 104 & 19.4 & 801.2 & 1795.4 & 61 & 27.78 & 63 \\
\hline Richardson Br. & 16 & 3.44 & 32 & 9.31 & 708.3 & 2039.1 & 160 & 76.21 & 78 \\
\hline Firwood & 2 & 3.75 & 90 & 23.98 & 269.1 & 661.0 & 26 & 16.97 & 74 \\
\hline Average & 23 & 5.95 & 94.375 & 18.19 & 967.1 & 1709.6 & $65.40^{*}$ & $31.94 *$ & 73.5 \\
\hline Total Average & $\mathbf{3 7 . 3 6}$ & 6.50 & 119.00 & 18.52 & 878.80 & 1644.08 & $52.00 *$ & 27.02* & 68.79 \\
\hline
\end{tabular}

* Repeated data for same LCA was only used once in calculating averages 


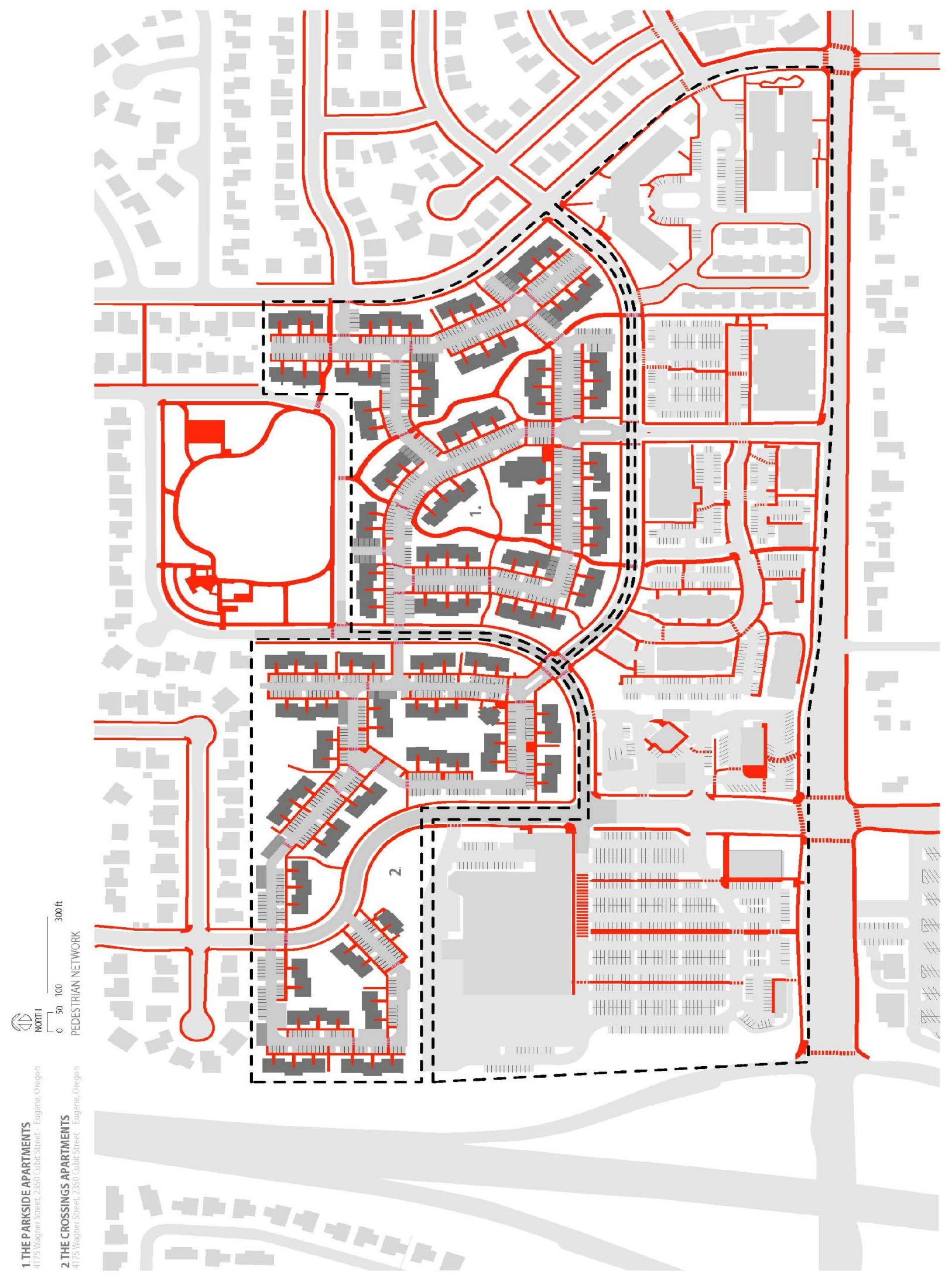

Figure 3.1: Connectivity criteria audit map, Eugene, Ore. 


\subsection{RESIDENT SURVEY}

In order to understand the travel habits of residents in suburban multifamily developments, we developed the Multifamily Housing Travel Survey and sent it to residents of the 14 case-study sites. The survey asked questions about residents' travel habits, how they choose their modes of transportation, and barriers to walking and biking. The survey consisted of 27 questions divided into six sections: transportation modes and frequency; transportation choices; ease of walking and biking; housing choice; demographic information; and a final section consisting of a mapping exercise. The survey was received by a total of 1,493 residents in March 2009. We used standardized survey distribution strategies, including an introductory postcard, a survey mailing, a follow-up postcard, and then a second mailing (Dillman 2000).

All study sites were surveyed simultaneously to avoid differences in weather, fuel costs and day length. The survey period had an even mix of sun and rain with daytime temperatures typically ranging between the mid-50s up into the 70s. In general, this area of Oregon has mild but wet winters, a mix of wet and dry springs and falls, and mild, dry, and pleasant summers, making walking and biking feasible throughout the year.

A total of 229 surveys were returned, representing a $15.3 \%$ response rate (130 out of 848 returned from well-connected sites (15.3\%) and 99 out of 645 from less-connected $(15.3 \%)$ ). This response rate did raise some questions as to how well the survey responses are representative of residents in general. Given the strength of many of the results outlined below, we do not feel that this is a major concern. The final analysis excluded individuals who did not have access to a car and hence used active transportation by necessity and not by choice. Incorporating this filter left 198 respondents in the analysis. Survey findings are discussed in section 4.2.

\subsection{RESIDENT FOCUS GROUP}

The surveys provided quantitative information to measure the habits and opinions of residents of suburban multifamily developments, but it was also important to gather qualitative information on specific problems and assets in terms of pedestrian connectivity. To address this, we planned a resident focus group where residents could be asked more specific questions about their development and travel habits, including:

- The frequency with which they travel to their commercial area, since the survey map did not inquire about frequency;

- Pedestrian barriers, shown on a map; and

- What their ideal development would look like.

Residents interested in participating in a focus group returned an interest form with their survey; over 40 of these forms were returned. Two focus groups were established, one for residents of two well-connected developments located in close proximity to each other and one for a series of five less-connected developments located along a major arterial road. Even though similar protocols used in earlier, successful focus group studies were applied here, the first focus group 
was not held due to poor attendance, and a second focus group was held with only three participants. Needless to say, the low attendance rate for focus groups limited the usefulness of this exercise. Future studies will incorporate a reward/incentive to increase focus group attendance.

\subsection{CODE ANALYSIS}

The second part of this study examined codes and practices of cities across the United States. The focus was how "progressive" cities regulated their development to promote connectivity. Along with Eugene, five other cities were identified and selected for code analysis relating to multifamily housing and transportation. Planners in each city were interviewed to help answer questions about their codes, including the development atmosphere in their city and links between sections of the code.

Progressive cities were identified using a range of sources. This included Susan Handy's report to the American Planning Association on "Planning for Street Connectivity" (Handy 2003), which identified several municipalities with progressive codes, suggestions solicited from several Internet listservs for transportation professionals, and discussions with professionals and academics at presentations and conferences. From those sources, the following six cities were chosen for the code analysis:

- Eugene, Ore.

- Asheville, N.C.

- Huntersville, N.C.
- San Jose, Calif.

- San Antonio, Texas

- Arlington, Va.

Sections of each city's code dealing with multifamily housing and automobile and pedestrian transportation were examined and compared. For ease of analysis, a spreadsheet of each city's code was created, organizing the relevant codes by major topic sections.

\subsection{PLANNER/DEVELOPER FOCUS GROUP}

To better understand the role of planners and developers in creating well-connected suburban multifamily housing developments, we held a focus group with planners and developers in the Eugene area. We invited individuals who were related to the design, development or review of multifamily housing developments to participate in the discussion. Seven participants attended, including two land-use planners, a transportation planner, a neighborhood association representative, a board member of a local non-profit, and a developer and an architect both involved with building and designing local multifamily housing.

There were three main topics of discussion: what might be preventing the creation of wellconnected developments (in terms of code language, development atmosphere, etc.); what factors influence the level of connectivity in a multifamily development; and what kind of information would be useful in a handbook about multifamily housing site design. 


\subsection{BEST PRACTICES HANDBOOK}

The information gathered throughout this project is being compiled in a Best Practices Handbook for planners, architects and developers to use when designing and reviewing new multifamily housing developments. The focus of the handbook is on site design that leads to well-connected developments and neighborhoods. From information gathered during this study, we developed 10 major topic sections that organize the handbook.

Table 3.2: Ten Principles for Well-Connected Multifamily Developments

\begin{tabular}{l|l}
\hline Access Points & Open Space and Landscape Design \\
\hline Bicycle Facilities & Parking \\
\hline Building Massing and Orientation & Relationship to Surrounding Developments \\
\hline Edges & Street Design \\
\hline Internal Pedestrian Network & Street Network \\
\hline
\end{tabular}

Each of these 10 criteria is developed in the handbook, showing why the criteria is important, how that element is usually executed in multifamily housing, ways to improve the element, and how other municipalities are improving that element. Each section includes photographic examples of less-connected and well-connected developments for comparison.

The following is an example of the comparisons that are made in the handbook. Figures 3.2 and 3.3 show examples of protected pedestrian paths and unprotected pedestrian paths. Similar comparisons will be made throughout the handbook to clearly show examples of how to create good connectivity. The handbook is currently being developed through another OTREC grant and will be available in Fall 2010.

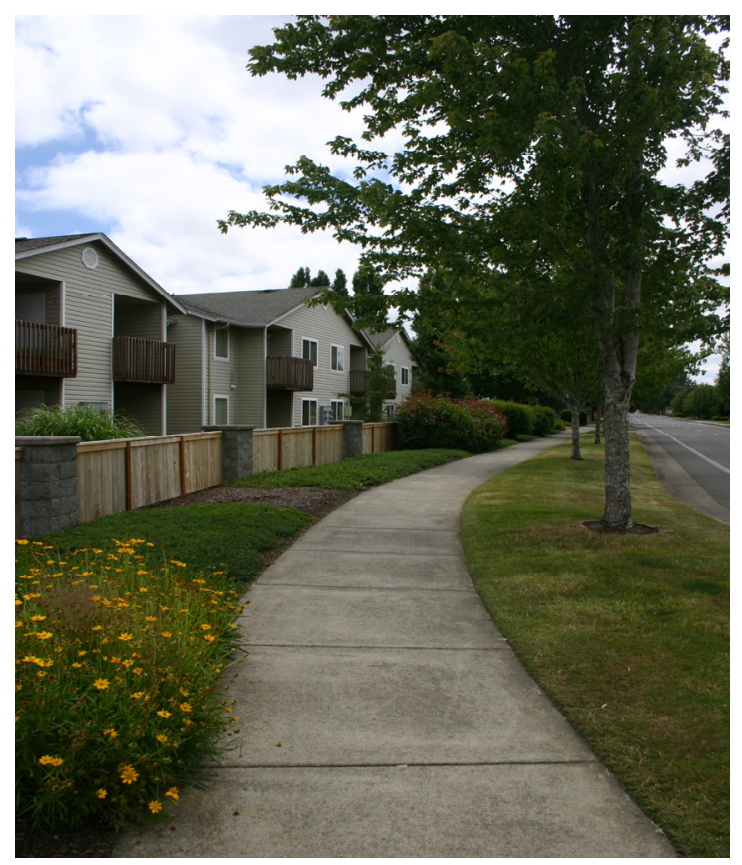

Figure 3.2: Protected pedestrian path, Corvallis, Ore.

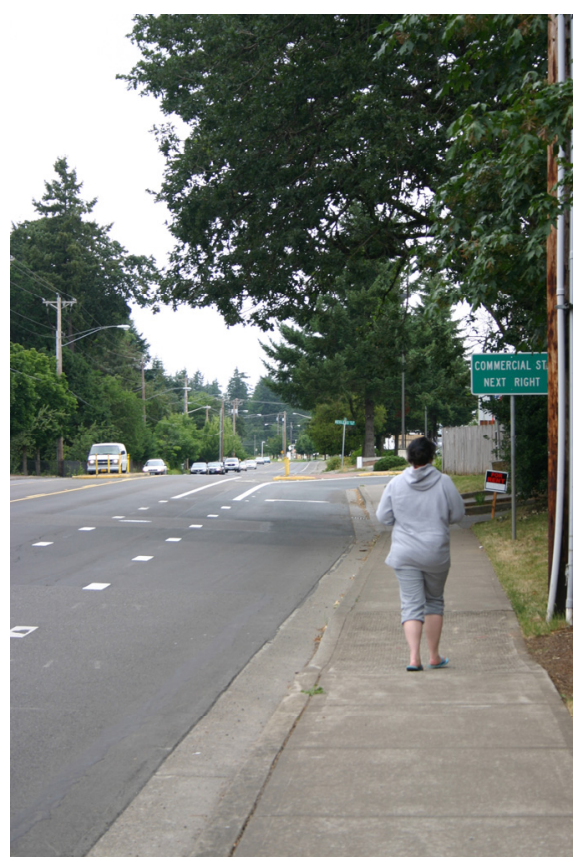

Figure 3.3: Unprotected pedestrian path, Salem, Ore. 


\subsection{FINDINGS \& RECOMMENDATIONS}

The findings from this project are organized into three categories:

1. Connectivity Criteria

2. Resident Travel Survey Findings

3. Code Review

\subsection{CONNECTIVITY CRITERIA}

Through the analysis of the connectivity criteria, we developed a ranking system that divided the 14 case-study sites into groups of well-connected and less-connected developments. The casestudy developments were ranked from most connected to least connected (shown in Table 4.1). The scores were generated out of 100 possible points that any development could achieve. The numbers in parentheses are these accessibility scores, meaning that with an accessibility score of 74 , Heron Meadows is the most connected development, while Firwood was the least connected development with an accessibility score of 2 .

Table 4.1: Case-Study Sites after Using the Connectivity Criteria

\begin{tabular}{l|l}
\hline Well-Connected & Less-Connected \\
\hline 1. Heron Meadows (74) & 7. Santa Clara Place (34) \\
\hline 2. The Crossings (69) & 8. Woodland Creek (30) \\
\hline 3. Parkside (61) & 9. \& 10. Oak Lane (27) \& Oak Meadow (27) \\
\hline 4. Sheldon Village (48) & 11. Riviera Village (23) \\
\hline 5. Green Leaf Village (46) & 12. Applewood (22) \\
\hline 6. Apple Orchard (44) & 13. Richardson Bridge (16) \\
\hline & 14. Firwood (2) \\
\hline
\end{tabular}

Some developments had mixed levels of connectivity when comparing internal and external connectivity. Developments like Apple Orchard and Greenleaf Village are both ranked low on the well-connected developments list, but they have good internal connectivity scores with lower external connectivity scores. The opposite is true for developments like Riviera Village and Applewood, which have the worst internal connectivity scores but higher external connectivity scores. Given the range of development conditions of each study site, this variation was expected. The idea behind the composite connectivity rankings was to enable us to group major trends of more and less connected development and compare overall survey results for these two categories.

After reviewing the connectivity criteria with experts in the field, we examined correlations between the measures and found some of these dimensions are positively correlated to each other while some are negatively correlated. 
Table 4.2: Connectivity Criteria Divided into Groups

\begin{tabular}{l|l}
\hline Major Groupings & Connectivity Measure \\
\hline \multirow{2}{*}{ 1. Connectivity } & Measure 1 - Internal Pedestrian Network (building to building) \\
\cline { 2 - 2 } & Measure 8 - External Protected Pedestrian Network \\
\hline 2. Node Density & Measure 3 - Node Density \\
\hline 3. Access Point Distribution & Measure 6 - Access Point Distribution \\
\hline 4. Route Directness & Measure 4 - Internal Pedestrian Route Directness \\
\cline { 2 - 2 } & Measure 7 - External Pedestrian Route Directness \\
\hline 5. Internal Auto Circulation and Pedestrian & Measure 5 - Pedestrian Friendliness of the Automobile Realm \\
\hline 6riendliness of the Automobile Realm & \\
\hline 6. Other & Measure 2 - Internal Pedestrian Network (building to egress) \\
\cline { 2 - 2 } & Measure 9- External Street Type \\
\hline
\end{tabular}

1) Connectivity $\rightarrow$ Measures 1 (internal continuous pedestrian network, building to building) and 8 (presence of a protected pedestrian path) are not highly correlated, meaning that a development can be well-connected internally but have poor pedestrian protection on the path to the commercial area.

2) Node Density $\rightarrow$ Measure 3 (node density) is highly correlated with measure 1, meaning that developments with more nodes in the internal pedestrian network also tend to have an internal pedestrian network that is more continuous.

3) Access Point Distribution $\rightarrow$ Measure 6 (access point distribution) is correlated with Measures 2 (internal pedestrian network), 7 (external pedestrian route directness), and 8 (external protected pedestrian path). This is interesting because Measure 6 describes an internal feature where Measures 7 and 8 are strictly external features.

4) Route Directness $\rightarrow$ Measures 4 (internal pedestrian route directness) and 7 (external pedestrian route directness) are negatively correlated with each other, meaning that developments with good internal route directness seem to have poor external route directness and vice versa. This seems to be a coincidence of the sites we have chosen, and not a rule.

5) Internal Auto Circulation and Pedestrian Friendliness of the Automobile Realm $\rightarrow$ Measure 5 (pedestrian friendliness of the automobile realm) examines the types of parking within developments (large parking lots being the least friendly for pedestrians and parking pods being the friendliest). Measure 5 is highly correlated with Measure 3, pedestrian node density, showing that a development with more nodes on the pedestrian network is more likely to have more pedestrian-friendly parking.

6) External Streets $\rightarrow$ Measure 9 (external street type) was most highly correlated with Measure 8 (external protected pedestrian path). Not surprisingly, this suggests that local streets are more highly correlated with protected pedestrian environments and autooriented streets in the study areas did not often mitigate the auto-oriented nature of the street with specifically designed protected pedestrian elements.

7) Internal Connectivity $\rightarrow$ Measures 2 (internal continuous pedestrian network, building to egress) was highly correlated with Measures 1 (internal pedestrian network), 3 (node 
density), and 6 (access point distribution). These measures all represent strong internal connectivity.

Overall, the measures of internal connectivity tend to be associated with each other and the measures of external connectivity tend to be associated with each other, but there is little connection between the two.

\subsection{RESIDENT TRAVEL SURVEY RESULTS}

The resident travel survey was divided into the following six sections: Travel Modes, Factors Influencing Transportation Choices, Ease of Walking and Biking, Housing Choices, Demographic Information, and a Mapping Exercise. The results from each of these sections are discussed below.

\subsubsection{Travel Modes}

The first two questions of the survey asked residents to estimate the total number of trips they made to their LCA in the past month and note the number of trips they made per week using four transportation modes: walking, biking, driving and public transportation. The LCA was defined for residents through a map showing their development, nearby streets, and the border of what we were considering to be each site's LCA. Walking was defined as including wheelchair use, while biking was defined as including any other non-motorized transportation with wheels (bicycle, skateboard, rollerblades, etc.).

We analyzed the results from these questions in two ways: first we looked at total trips and percentage of trips by each mode (shown in Table 4.3) and next we looked at each individual's travel behavior and the percentage of individuals making different mode choices (shown in Table 4.4).

Table 4.3: Percent of Trips Per Week by Travel Mode (shown as percentages)

\begin{tabular}{|l|c|c|c|}
\hline Travel Mode & \multicolumn{3}{|c|}{ Mean Percent of Trips Made by Mode } \\
\hline & Both & Well-Connected & Less-Connected \\
\hline Driving & 60.5 & 54.0 & $71.1^{*}$ \\
\hline Walking & 35.7 & 43.0 & $23.7^{* *}$ \\
\hline Biking & 3.0 & 1.7 & 5.1 \\
\hline Biking or Walking & 38.7 & 44.7 & 28.8 \\
\hline$* \mathrm{p}<.05, * * \mathrm{p}<.01$ & $\mathrm{n}=197$ & $\mathrm{n}=123$ & $\mathrm{n}=74$
\end{tabular}

Contrary to popular perception as well as studies regarding mode choice in suburbia (Ewing, Schmid et al. 2003), residents reported a substantial amount of active transportation trips across both well-connected and less-connected developments. As shown in Table 4.3, across all sites more than a third of all trips to the LCA are active transportation trips (38.7\%), with a large majority of those trips being walking trips. 
In addition, travel-mode use and connectivity are significantly associated. Residents of wellconnected sites are significantly less likely to drive to the LCA than residents of less-connected sites. Just over half $(54.0 \%)$ of the trips to the LCA were driving trips for residents of wellconnected sites versus $71.1 \%$ for residents in less-connected sites. A significantly larger percentage of trips, nearly double, are walking trips in well-connected sites $(43.0 \%)$ as compared to less-connected sites (23.7\%). The development with the highest percentage of active transportation trips was Sheldon Village with $72.0 \%$ of all trips, and the lowest was Richardson Bridge with only $12.5 \%$. It is important to note that all of these figures do not include individuals who did not have access to a car and, therefore, underrepresents the total amount of active travel actually occurring in these developments.

Table 4.4: Travel Mode by Site Connectivity (shown as percentages)

\begin{tabular}{l|c|c|c}
\hline Travel Mode Used & Both & Well-Connected & Less-Connected \\
\hline Ever Walk & 65.2 & 72.6 & $52.7^{* *}$ \\
\hline Ever Bike & 9.6 & 6.5 & $14.9^{*}$ \\
\hline Ever Walk or Bike & 67.5 & 73.2 & $58.1^{*}$ \\
\hline Walk or Bike Only & 16.2 & 20.3 & $9.5^{*}$ \\
\hline Ever Drive & 82.8 & 78.2 & $90.5^{*}$ \\
\hline Drive Only & 32.5 & 26.8 & $41.9^{*}$ \\
\hline Mostly Walk & 36.9 & 44.4 & $24.3^{* *}$ \\
\hline Mostly Drive & 58.1 & 51.6 & $68.9^{*}$ \\
\hline$* \mathrm{p}<.05, * * \mathrm{p}<.001$ & $\mathrm{n}=198$ & $\mathrm{n}=124$ & $\mathrm{n}=74$ \\
\hline
\end{tabular}

When looking at the data in terms of an individual's travel behavior, there are two interesting findings in the results from this set of questions. The first is that, again, contrary to popular beliefs about walking and biking in suburbia, there are a large number of individuals choosing active transportation to travel between suburban multifamily housing and LCAs. Nearly $68 \%$ of respondents reported taking at least one active transportation trip per week to their LCA.

A second finding is that the travel mode a person chooses for trips to their LCA is significantly associated with the level of connectivity of the development they live in. People who live in well-connected developments are more likely to choose active transportation modes than those who live in less-connected development. Almost three quarters (73\%) of people living in wellconnected developments walk to their LCA at least once a week versus just over half (53\%) of people in less-connected developments. In addition, over twice the percentage of residents in well-connected developments $(20.3 \%)$ versus less-connected development $(9.5 \%)$ only walk or bike to their LCA.

\subsubsection{Factors Influencing Transportation Choices}

The transportation choices section of the survey asked residents to rate reasons why they drive and reasons why they walk or bike to their LCA. Respondents were asked to rate the importance of specific factors related to making their travel decisions and to list the top three factors that influenced their mode choice. Table 4.5 shows the reasons why residents might drive to their LCA and the percentage of residents who listed the reason as one of their top three choices. 
Residents of well-connected and less-connected developments listed the same reasons as the three most important:

- I often combine trips to my LCA with trips to other destinations that require a car $(68.8 \%$, $67.4 \%)$.

- There is too much for me to carry, so I can't walk or bike $(67.6 \%, 52.7 \%)$.

- I do not like to walk or bike in bad weather $(57.6 \%, 39.2 \%)$. (Note: This answer may be slightly higher than studies in other areas because of the rainy climate in Oregon.)

Table 4.5: Driving Factors

(shown as percentages)

\begin{tabular}{l|c|c|c}
\hline Driving Factors & Both & Well-Connected & Less-Connected \\
\hline $\begin{array}{l}\text { I often combine trips to my local commercial area with } \\
\text { trips to other destinations that require a car. }\end{array}$ & 68.2 & 68.8 & 67.4 \\
\hline There is too much for me to carry, so I can't walk or bike. & 62.0 & 67.6 & 52.7 \\
\hline I do not like to walk or bike in bad weather. & 50.6 & 57.6 & 39.2 \\
\hline I don't have enough time to walk or bike. & 29.3 & 29.6 & 28.7 \\
\hline $\begin{array}{l}\text { I don't feel safe walking or biking because of vehicle } \\
\text { traffic. }\end{array}$ & 25.5 & 20.4 & 34.0 \\
\hline $\begin{array}{l}\text { I have to cross too many busy streets between my home } \\
\text { and my local commercial area. }\end{array}$ & 15.3 & 12.3 & 20.4 \\
\hline Crime in the area keeps me from walking and biking. & 9.7 & 6.2 & 15.4 \\
\hline $\begin{array}{l}\text { The distance from my residence to my local commercial } \\
\text { area is too far for me to walk or bike. }\end{array}$ & 6.9 & 8.0 & 5.1 \\
\hline $\begin{array}{l}\text { I don't like the look or feel of the walking and biking } \\
\text { route to my local commercial area. }\end{array}$ & 4.4 & 3.1 & 6.8 \\
\hline $\begin{array}{l}\text { Having to go through parking lots within my apartment } \\
\text { complex prevents me from biking or walking. }\end{array}$ & 3.9 & 3.1 & 5.1 \\
\hline $\begin{array}{l}\text { There is no direct walking or biking path to my local } \\
\text { commercial area. }\end{array}$ & 3.2 & 4.1 & 1.7 \\
\hline $\begin{array}{l}\text { There are no sidewalks, crosswalks, or bike lanes to walk } \\
\text { or bike on. }\end{array}$ & 1.9 & 1.1 & 3.4 \\
\hline Other & 18.9 & 18.3 & 20.2 \\
\hline
\end{tabular}

Table 4.6 shows the results of the second question in this section about reasons why residents might walk or bike rather than drive to their LCA. Again, residents of both types of developments picked the same three reasons as most important:

- Walking and biking is better for my health $(92.1 \%, 90.6 \%)$.

- Walking and biking is better for the environment $(72.3 \%, 67.7 \%)$.

- I want to save money $(56.4 \%, 61.8 \%)$. 
One interesting difference is that a greater percentage of residents in well-connected developments believe that it is faster to walk or bike to their commercial area than it is to drive ( $27 \%$ compared to $16 \%$ in less-connected developments).

Table 4.6: Walking and Biking Factors

(shown as percentages)

\begin{tabular}{l|c|c|c}
\hline Walking and Biking Factors & Both & Well-Connected & Less-Connected \\
\hline Walking or biking is better for my health. & 91.5 & 92.1 & 90.6 \\
\hline Walking or biking is better for the environment. & 70.8 & 72.3 & 67.7 \\
\hline I want to save money. & 58.4 & 56.4 & 61.8 \\
\hline $\begin{array}{l}\text { It is faster to walk or bike to my local commercial } \\
\text { area than it is to drive. }\end{array}$ & 22.9 & 26.7 & 15.5 \\
\hline Parking at my local commercial area is difficult. & 12.5 & 13.9 & 9.9 \\
\hline $\begin{array}{l}\text { I often combine trips that involve walking or biking, } \\
\text { and my local commercial area is on the way. }\end{array}$ & 9.8 & 8.9 & 11.7 \\
\hline I do not have access to a car. & 8.5 & 7.9 & 9.5 \\
\hline $\begin{array}{l}\text { I enjoy seeing and meeting other people when I walk } \\
\text { or bike. }\end{array}$ & 8.6 & 3.0 & 19.8 \\
\hline Parking in my development is difficult. & 5.9 & 6.9 & 3.8 \\
\hline Other & 11.1 & 11.9 & $\mathrm{n}=101$ \\
\hline
\end{tabular}

Overall, residents of both well-connected and less-connected developments show similar attitudes in ranking factors that affect their travel decisions, but simultaneously have very different travel behaviors. Given that the primary difference between the two groups is the level of connectivity in the development, this suggests that the built environment is playing a key role in travel decisions.

\subsubsection{Ease of Walking and Biking}

The third section of the survey asked residents questions about the ease of walking and biking within their development as well as between their development and the LCA. Table 4.7 shows the responses by well-connected and less-connected residents. Results from this table show that the perception of the ease of walking and biking is not significantly associated with a site's internal connectivity. However, the perception of the ease of walking and biking is significantly associated with the level of connectivity between a resident's development and LCA (external connectivity). Residents in well-connected developments are more likely to think that it is easy to walk to their LCA than residents in less-connected sites. Also, over half $(55 \%)$ of the respondents from well-connected sites thought that walking or biking to their LCA was very easy versus only $31 \%$ of residents in less-connected sites.

When asked if they would walk or bike more if it were made easier to do so, residents of wellconnected and less-connected developments gave significantly different responses. Table 4.8 shows the responses to this question, which was asked to understand the impact that changes to the built environment could have on behavior. Seventy percent of respondents in well-connected 
developments said it was already easy and convenient to walk and bike versus only $36 \%$ in lessconnected sites. Related to this, more respondents from less-connected sites are likely to change their behavior if circumstances around them change (39\% for less-connected vs. $20 \%$ for wellconnected developments). This suggests that changes to the built environment would correlate to substantial changes in walking and biking behavior and, not surprisingly, that the changes would be most effective in areas that currently have lower connectivity.

Table 4.7: Perception of Ease of Walking and Biking (shown as percentages)

\begin{tabular}{l|l|c|c|c}
\hline \multirow{2}{*}{ Not Easy (1) } & & Both & Well-Connected & Less-Connected \\
\hline \multirow{2}{*}{2} & Within & 2.1 & 2.8 & 1.6 \\
\cline { 2 - 5 } & To LCA & 3.6 & 2.4 & $5.6^{*}$ \\
\hline \multirow{3}{*}{3} & Within & 1.0 & 0.8 & 1.4 \\
\cline { 2 - 5 } & To LCA & 6.7 & 4.9 & $9.7^{*}$ \\
\hline \multirow{3}{*}{4} & Within & 12.3 & 19.7 & 8.1 \\
\cline { 2 - 5 } & To LCA & 19.5 & 14.6 & $27.8^{*}$ \\
\hline \multirow{2}{*}{ Very Easy (5) } & Within & 24.1 & 24.2 & 23.9 \\
\cline { 2 - 5 } & To LCA & 24.6 & 23.6 & 52.1 \\
\hline$* \mathrm{p}<.05, * * \mathrm{p}<.01$ & Within & 60.5 & 65.3 & $30.6^{*}$ \\
\cline { 2 - 5 } & To LCA & 45.6 & 54.5 & $\mathrm{n}=74$ \\
\hline
\end{tabular}

Table 4.8: Would you walk or bike more if it were made easier or more convenient to do so? (shown as percentages)

\begin{tabular}{l|c|c|c}
\hline Connectivity & Both & Well-Connected & Less-Connected \\
\hline Yes & 26.9 & 19.8 & $38.9 * * *$ \\
\hline No, it's already convenient & 57.5 & 70.2 & $36.1 * * *$ \\
\hline $\begin{array}{l}\text { No, it wouldn't influence } \\
\text { my decision }\end{array}$ & 15.5 & 9.9 & $25.0 * * *$ \\
\hline $\begin{array}{l}* \mathrm{p}<.05, * * \mathrm{p}<.01, \\
* * * \mathrm{p}<.001\end{array}$ & $\mathrm{n}=197$ & $\mathrm{n}=123$ & $\mathrm{n}=74$ \\
\hline
\end{tabular}

\subsubsection{Housing Choices}

The survey also asked residents how they chose their homes to examine how attitudes towards housing selection vary and to control for self-selecting biases that might exist. If residents specifically choose their housing based on how much it supports active travel, the differences we have reported above might simply be the results of a self selection of "active travel leaning" residents into the more-connected environments. As with earlier questions, the results shown in Table 4.9 indicate that residents of both types of developments have similar attitudes in regards to housing selection and chose the same top three answers to this question:

- $\quad$ Rent price $(76.3 \%, 83.5 \%)$.

- Characteristics of the residence itself (size, etc.) $(65.7 \%, 48.7 \%)$.

- $\quad$ Safety from crime $(44.9 \%, 54.9 \%)$. 
For both well- and less-connected developments, ease of walking or biking to any designated location ranked at the bottom of the list. This finding would again indicate that residents are not self-selecting based on a preferred mode of travel and that the built environment is likely contributing to the noted differences in travel modes.

A few differences do exist in resident responses to this question. A greater percentage of residents of less-connected developments indicated that they care about the proximity to their place of work when making their decision (46\% vs. 28\%), showing that a shorter travel distance between their home and place of work is a deciding factor in where they will live.

Table 4.9: Factors that affected your housing choice.

(shown as percentages)

\begin{tabular}{l|c|c|c}
\hline Housing Factors & Both & Well-Connected & Less-Connected \\
\hline Rent price & 78.8 & 76.3 & 83.5 \\
\hline Characteristics of the residence itself (size, etc.) & 59.6 & 65.7 & 48.7 \\
\hline Safety from crime & 48.5 & 44.9 & 54.9 \\
\hline Proximity to place of work & 34.6 & 28.4 & 45.7 \\
\hline Amenities within apartment complex (pool, gym, etc.) & 20.0 & 23.4 & 13.8 \\
\hline Ease of walking or biking to stores \& restaurants & 18.7 & 22.4 & 12.2 \\
\hline Ease of walking or biking to public transportation & 17.7 & 18.1 & 16.8 \\
\hline Ease of walking or biking to open space or parks & 15.5 & 15.6 & 15.3 \\
\hline Ease of walking or biking to a neighborhood school & 6.6 & 5.2 & 9.1 \\
\hline
\end{tabular}

\subsubsection{Demographic Information}

Table 4.10 compares the demographic characteristics of survey respondents. Related to the difference in age of developments, as expected, residents of the well-connected developments were often economically better off than residents of less-connected developments. Respondents from the well-connected developments also tended to be younger and slightly more educated than residents of less-connected developments. Also, there was a slightly larger percentage of residents in less-connected developments that described their households as "Married/partner with children." Both groups, however, were similar in regards to gender and race.

Table 4.10: Demographic Characteristics of Residents (shown as percentages)

\begin{tabular}{l|c|c|c}
\hline & All & Well-Connected & Less-Connected \\
\hline Age & & & \\
\hline $18-29$ & 35.4 & 41.9 & 24.3 \\
\hline $30-45$ & 26.8 & 27.4 & 25.7 \\
\hline 45 and older & 37.9 & 30.6 & 50.0 \\
\hline Income & & & \\
\hline Less than $\$ 30,000$ & 56.6 & 48.4 & 20.3 \\
\hline$\$ 30,000-\$ 50,000$ & 27.6 & 32.0 & 5.4 \\
\hline$\$ 50,000-\$ 70,000$ & 10.7 & 13.9 & 2.7 \\
\hline$\$ 70,000-\$ 90,000$ & 3.6 & 4.1 & 1.2 \\
\hline More than $\$ 90,000$ & $1.5 \%$ & 1.9 & \\
\hline Gender & & & \\
\hline
\end{tabular}




\begin{tabular}{l|c|c|c}
\hline Male & 29.2 & 32.2 & 24.3 \\
\hline Female & 70.8 & 67.8 & 75.7 \\
\hline & $\mathrm{n}=198$ & $\mathrm{n}=124$ & $\mathrm{n}=74$ \\
\hline
\end{tabular}

Based on some of the differences in demographics, we looked at several control variables, including age, income, gender and education, which might explain differences in travel mode choice between the well-connected and less-connected developments. We also looked at control variables relating to differences in study-site size and distance to the LCA. We measured size by both acreage and number of units, while distance was measured both as an "as the crow flies" distance as well as a pedestrian/street-network distance. In multiple combinations of variables, site connectivity consistently showed the best fit with resident mode choice, suggesting demographic differences between well-connected and less-connected respondents and differences in distance to LCA or size of study site were not responsible for resident mode choice. Only one demographic characteristic, gender, was significantly related to number and percentage of trips, with males making more active trips and having a higher percentage of their trips being active. Independent of this, everyone - males and females - were more active in the well-connected complexes.

Table 4.10 (continued): Demographic Characteristics of Residents

\begin{tabular}{|c|c|c|c|}
\hline & All & Well-Connected & Less-Connected \\
\hline \multicolumn{4}{|l|}{ Household Type } \\
\hline Single with no children & 37.1 & 38.9 & 34.6 \\
\hline Single with children & 16.1 & 15.3 & 17.3 \\
\hline Married/partner with no children & 17.7 & 16.7 & 19.2 \\
\hline Married/partner with children & 16.9 & 12.5 & 23.1 \\
\hline $\begin{array}{l}\text { Multiple adults (related or unrelated) } \\
\text { with no children }\end{array}$ & 8.9 & 13.9 & 1.9 \\
\hline $\begin{array}{l}\text { Multiple adults (related or unrelated) } \\
\text { with children }\end{array}$ & 3.2 & 2.8 & 3.8 \\
\hline \multicolumn{4}{|l|}{ Race } \\
\hline American Indian or Alaska Native & 1.6 & 2.5 & 0.0 \\
\hline Native Hawaiian or Pacific Islander & 1.1 & 0.8 & 1.4 \\
\hline Asian & 3.2 & 3.4 & 2.9 \\
\hline Black or African-American & 2.1 & 1.7 & 2.9 \\
\hline Latino/Hispanic & 4.8 & 3.4 & 7.1 \\
\hline White/Caucasian (non-Hispanic) & 87.2 & 88.1 & 85.7 \\
\hline \multicolumn{4}{|l|}{ Education } \\
\hline High School & 29.5 & 24.4 & 38.0 \\
\hline College & 56.8 & 58.0 & 54.9 \\
\hline \multirow[t]{2}{*}{ Post Graduate } & 13.7 & 17.6 & 7.0 \\
\hline & $\mathrm{n}=198$ & $n=124$ & $n=74$ \\
\hline
\end{tabular}

*All results are significant at $\mathrm{p}<.05$ level

\subsubsection{Mapping Exercise}

In the final section of the survey, we presented residents with an aerial map of their development and the surrounding commercial area. We then asked residents to mark where they live with an " $\mathrm{x}$ " and circle all of the places they went in the last month (including stores, restaurants, banks, 
friend's house, parks, etc.). Next, we asked residents to draw lines showing the exact route they take only if they walked or biked to these destinations.

A prevalent trend in the resident responses was that jaywalking was very commonplace. In locations where crosswalks or traffic lights were not within the direct path to destinations, residents would often draw a line crossing a road in the middle of a block, away from a crosswalk. This finding is similar to that of Hess et al. (1999), who completed a study of people's walking behavior in suburban areas and found that 32 percent of suburban residents jaywalked when trying to get to a commercial area versus 20 percent in urban sites. They noted that "the very high incidence of jaywalking in suburban sites suggests that pedestrians take risks because they lack options in their walking routes, and this points to a major safety problem" (Hess et al. 1999).

The map data is still in the process of being analyzed using geographic information systems (GIS). Respondents' travel routes will be evaluated with the most direct pedestrian routes to compare the path lengths and potential barriers to pedestrian activity. This information will be available at a later date.

\subsubsection{Resident Focus Group}

The resident focus group provided information complimentary to the surveys. Participants discussed how time is the biggest factor limiting walking and biking activity, especially in lowerincome areas where people might have more than one job. An older participant noted a large amount of walking and biking to her commercial area as she was retired, while a couple with a young child noted relatively little walking and biking because of time constraints with multiple jobs, school and raising a child.

When asked about elements of their ideal development, residents listed the following items:

- Bicycle facilities

- Trees (for shade and safety)

- Considerate drivers

- Access to parks
- Aesthetically pleasing paths

- Well-lit paths and roads

- Safer crossing facilities

Safety was discussed as the largest concern with walking and biking. Living along a highvolume arterial road made the residents feel unsafe using the sidewalk or biking along the road. The area where the residents lived is an area with a high homeless population, which all participants noted as a safety concern, especially walking or biking in the dark. They discussed how adequate lighting might influence their decision, both overhead lighting and more crosswalks with pedestrian lights. Participants also discussed having limited access to bike facilities like secure racks and covered parking, and access to these facilities might increase their desire to use a bicycle. 
While these findings were consistent with the information gathered through the survey, it should be noted that the focus groups had very limited participation, only included residents of lessconnected developments, and cannot be considered descriptive of the population as a whole.

\subsection{CODE REVIEW}

City codes provide the foundation for development, guiding development to fulfill certain goals. This study looked at six cities' codes to compare their requirements for several elements that make for well-connected, pedestrian-friendly neighborhoods. Table 4.11 outlines a few of the most critical elements within the six case-study cities. In general, there is substantial overlap between these codes in the topics they cover and presumably therefore see as most critical to creating successful multifamily development. Connectivity-related topics include parking, sidewalks, bike parking, open space design, street landscaping and building street frontage.

All codes required a full pedestrian network of sidewalks that connect all buildings to each other and to other amenities on site. Parking was dealt with in different ways across the different jurisdictions, but a general trend of trying to minimize the impact of parking and automobiles on the pedestrian realm was consistent. This was represented as either minimizing the centrality of parking (parking underground or behind buildings) or mitigating the extent of parking (focusing on parking courts or minimizing continuous rows of parking). Bike parking was almost universally required or heavily encouraged. Across codes, buildings were often either encouraged or required to front on streets instead of on parking areas or open spaces.

Although we have collected all of the codes and have done a preliminary analysis of them, due to time limitations and an expanded list of model codes to review, we have only arrived at initial findings at this point. An expanded analysis of these codes is currently underway and we are incorporating this analysis into the Best Practices Handbook being developed through another OTREC grant.

Table 4.11: Case-Study City Codes

\begin{tabular}{l|l|l|l|l|l|l}
\hline Element & Arlington & Asheville & Eugene & Huntersville & San Antonio & San Jose \\
\hline Parking & $\begin{array}{l}\text { Underground } \\
\text { where } \\
\text { possible }\end{array}$ & $\begin{array}{l}\text { Landscaping } \\
\text { required }\end{array}$ & $\begin{array}{l}\text { Emphasize } \\
\text { parking } \\
\text { courts }\end{array}$ & $\begin{array}{l}\text { Parking } \\
\text { behind } \\
\text { buildings }\end{array}$ & $\begin{array}{l}\text { Reasonable } \\
\text { maximum } \\
\text { parking spaces }\end{array}$ & $\begin{array}{l}\text { No more than } 14 \\
\text { spaces in a row } \\
\text { without a bulb }\end{array}$ \\
\hline Sidewalks & Required & Required & Required & Required & Required & Required \\
\hline Bike Parking & Required & $\begin{array}{l}5 \% \text { of auto } \\
\text { spaces }\end{array}$ & - & $\begin{array}{l}\text { Encouraged } \\
\text { in all non- } \\
\text { residential } \\
\text { areas }\end{array}$ & Required & $\begin{array}{l}1 \text { space per } 2 \\
\text { units }\end{array}$ \\
\hline Open Space & $20 \%$ of site & $\begin{array}{l}500 \text { sq. ft. } \\
\text { per unit }\end{array}$ & - & $\begin{array}{l}\text { Within 1/2 mi } \\
\text { of all lots }\end{array}$ & - & $\begin{array}{l}\text { Must be visible } \\
\text { from street }\end{array}$ \\
\hline Street Landscaping & $\begin{array}{l}4-6 \text { feet wide } \\
\text { planting strip }\end{array}$ & Required & - & Required & Required & $\begin{array}{l}1 \text { tree for every } \\
\text { 25 ft. of street }\end{array}$ \\
\hline Street Frontage & Required & - & Required & Required & - & $\begin{array}{l}\text { Up to 50\% of } \\
\text { parking may be } \\
\text { in front of bldg. }\end{array}$ \\
\hline
\end{tabular}




\subsubsection{Planner Interviews}

In addition to code reviews, we also interviewed planners in each of the six case-study cities. These interviews provided insight that examining the code by itself could not. The most-often mentioned deterrent to creating better connectivity was the politics involved in development, both between government and developers as well as between developers. A common complaint was that planners sometimes think that developers are trying to get away with something, while developers feel like planners do not understand the realities of development and enforce unnecessary regulations.

Huntersville provided an interesting example of developers working together. Because the landscape in Huntersville lends itself to the division of property lines along streams, developments must work together to create stream crossings. This leads to developments being connected together in unique ways since a planner noted the public discomfort with stubbed out streets at the property lines because of fears of crime and public garbage dumping. Arlington also provided an example of developers and planners working together early on as part of their site planning process. This process was central to letting developers and planners work through any misunderstandings or issues with the plan, prior to approval by the County Board.

Planners also went into more depth about the community perception of barriers to multifamily housing. There is a fear of the increased density and the sense of the decline in the quality of life that could come with multifamily housing. While developers are often interested in building at higher densities, the public reaction to density and the potential that this will create costly delays in project development are often considered to be barriers to projects. Planners saw the public process and design as a critical element to mitigate public fears. A planner from Asheville said that site landscaping, open space, and parking-lot landscaping can ameliorate these fears. Incentives can also help encourage developers to build higher-density, well-connected developments, and planners mentioned specific incentives already in place. In San Jose, properties within 2,000 feet of a transit station are allowed to provide $10 \%$ fewer parking spaces. San Antonio waives fees for putting in bus stops along transit lines in new developments as well as shared parking between properties.

Planners also discussed the role of multifamily housing as a transitional development. In Huntersville, multifamily housing is often a transition between commercial areas and singlefamily housing, as is the case in many cities. Multifamily housing is also a transition between single-family housing and transit facilities in Huntersville since the greater density of multifamily housing is better suited to transit. A planner from Arlington also said that multifamily housing is used as a transitional element between single-family housing and other land uses, and he believed that this was a positive aspect of multifamily developments if they are of high quality.

In general, planners seemed to agree that design of multifamily developments was a critical aspect both in the public perception of projects and in their actual functionality. Connectivity was seen as an important factor to be considered when developing multifamily projects, especially as it related to connections to commercial areas. Connection to single-family areas, in contrast, was often considered to be a potentially volatile political issue. 


\subsubsection{Eugene Planner/Developer Focus Group}

Eugene-based planners and developers participating in the focus group were candid in their discussion of what was preventing them from making well-connected multifamily developments. Developers and designers spoke about how city codes contradict themselves and can be easily misinterpreted because of vagueness. Planners agreed and said(?) these codes are purposefully vague as to not prescribe certain ways of development, but to allow flexibility in development. All agreed, however, that it is difficult to align development standards towards a common goal because of the vagueness in code language.

Many of the participants mentioned that perceived safety among residents and property owners is a significant reason for less-connected developments. Residents fear that their development will be used as a walkthrough for people they may not want in their development, which may lead to an increase in property or personal crimes or an increase in the fear of these crimes. Participants also noted that property owners of multifamily housing developments have similar safety concerns. Other researchers have echoed these sentiments about safety and alternative transportation, though some believe that proper design is the key to calming these concerns (Handy et al. 2003).

After this discussion, participants contributed their thoughts on elements of a well-connected multifamily development and the surrounding neighborhood. The most often mentioned elements are listed in Table 4.12.

Visitability and security are two elements that were mentioned with great frequency. The concept of visitability was mentioned in early discussions in the focus group, and the group seemed to gather around that term. According to the Visitability Initiative at the University of Buffalo, visitability is "an affordable, sustainable and inclusive design approach for integrating basic accessibility features into all newly built homes and housing" (CIDEA 2006). Other important elements of well-connected developments that were mentioned were providing multiple modes of transportation, incentives and low cost for developers, and creating more direct and clear communication between planners and developers to reach a common goal.

Table 4.12: Elements that Might Influence the Level of Connectivity in Multifamily Developments

\begin{tabular}{l|l}
\hline Visitability & Appropriate Standards \\
\hline Security & Understandable Code \\
\hline Multiple Modes of Transportation & Mix of Uses \\
\hline Incentives & Adjustments to Code are Allowed \\
\hline Low Cost & Good Design \\
\hline $\begin{array}{l}\text { Communication Between Planners and } \\
\text { Developers }\end{array}$ & \\
\hline
\end{tabular}




\subsection{CONCLUSION}

The results of this study show that, contrary to common perceptions, there is a substantial amount of pedestrian activity in and around suburban multifamily developments and that more connected sites result in more active travel. The amount of this travel, however, and the percentage of individuals engaged in it is dependent on site connectivity. Suburban multifamily development patterns have followed the typical enclaved site-design strategies seen throughout suburbia. These site-design strategies are, quite literally, barriers to capitalizing on the potential health, economic, environmental and social benefits of fostering more active travel in suburbia. These results should give planners and designers reason to improve suburban multifamily site connectivity and should lead to a re-evaluation of local zoning and design guidelines.

While this study focused on active transport from suburban multifamily housing developments to LCAs, the results suggest that there may be additional latent active transport in suburbia that involves single-family residents' travel to LCAs as well as both single-family and multifamily housing residents' travel to other destinations such as parks, schools, offices and other residences. In looking at these types of trips, researchers should give attention to the passthrough connectivity of large-lot developments such as suburban multifamily housing. A lack of direct connections across sites may be an impediment to travel paths with both sources and destinations outside of the sites in question.

Further study of existing travel patterns in these areas of suburbia and the effects of connectivity on mode choice in these areas is a critical next step in understanding the full potential of active travel in suburbia. 


\section{REFERENCES}

A. Agrawal et al. "How Far, by Which Route and Why? A Spatial Analysis of Pedestrian Preference." Journal of Urban Design, 13(1): 81-98, 2008.

Center for Inclusive Design and Environmental Access (CIDEA). The Visitability Initiative. University of Buffalo. http://www.ap.buffalo.edu/idea/Visitability/index.asp.

K.A. Danielsen, R.E. Lang, et al. "Retracting Suburbia: Smart Growth and the Future of Housing." Housing Policy Debate, 10(3): 513-540, 1999.

D. Dillman. Mail and Internet Surveys: The Tailored Design Method. J. Wiley, New York, 2000.

A. Forsyth and M. Southworth. "Guest Editorial: Cities Afoot - Pedestrians, Walkability, and Urban Design.” Journal of Urban Design, 13(1): 1-3, 2008.

L.D. Frank et al. Health and Community Design: The Impact of the Built Environment on Physical Activity. Island Press, Washington, D.C. 2003.

L. Freeman. "The Effects of Sprawl on Neighborhood Social Ties: An Explanatory Analysis." Journal of the American Planning Association, 67(1): 69-77, 2001.

S. Handy et al. "Planning for Street Connectivity: Getting from Here to There." American Planning Association Planning Advisory Service, Report Number 515, 2003.

P.M. Hess et al. "Site Design and Pedestrian Travel.” Transportation Research Record, 1674. Paper No. 99-0424: 9-19, 1999.

N. Larco. "Suburbia Shifted: Overlooked Trends and Opportunities in Suburban Multifamily Housing," Journal of Architectural and Planning Research, 27(1), 69-87, May 2010.

N. Larco. "Untapped Density: Site Design and the Proliferation of Multifamily Housing," Journal of Urbanism, 2(2): 167-186, July 2009.

N. Larco. "Discovering Fringe Urbanism: An Investigation into the Overlooked Suburban Multifamily Housing Typology." Vernacular Architecture Forum Annual Conference. Butte, Montana, 2009.

N. Larco. "Semi-Urban Suburbia: An Overlooked Multifamily Housing Type and Its Effects on a Shifting Suburbia." Proceedings from Fresh Air, the $95^{\text {th }}$ ACSA Annual Meeting, Philadelphia, PA, ACSA, 2007. 
C. Lewis et al. "Evaluation of the Effects of Ramp Location on Land Use and Development." Research Report No. 10-1762-3, Center for Transportation Research, University of Texas at Austin, 1999.

K.M. Leyden. "Social Capital and the Built Environment: The Importance of Walkable Neighborhoods." American Journal of Public Health 93(9): 1546-1551, 2003.

A.V. Moudon and P.M. Hess. "Suburban Clusters: the Nucleation of Multifamily Housing in Suburban Areas of the Central Puget Sound." Journal of the American Planning Association 66(3): 243-264, 2000.

P. Newman and J. Kenworthy. Sustainability and Cities: Overcoming Automobile Dependence. Island Press, Washington, D.C., 1999.

R. B. Peiser. "Density and Urban Sprawl.” Land Economics 65(3): 193-205, 1989.

D. Rafter. "Multifamily Housing Stronger than Other Commercial Construction." Commercial Real Estate News, August 17, 2009. http://www.rejournals.com/markets/212963-multi-familyhousing-stronger-than-other-commercial-construction-sectors

T. Randall and B. Baetz. "Evaluating Pedestrian Connectivity for Suburban Sustainability." Journal of Urban Planning and Development, 127(1): 1-15, 2001.

M. Southworth. "Designing the Walkable City." Journal of Urban Planning and Development, 131(4): 246-257, 2005.

United State Census Bureau. 2000 Census and Annual American Community Surveys.

United States Green Building Council. "Development Density and Community Connectivity." Leadership in Energy and Environmental Design, 2005. 



\section{SOTREC \\ AND EDUCATION CONSORTIUM}

P.O. Box 751

Portland, OR 97207

OTREC is dedicated to stimulating and conducting collaborative multi-disciplinary research on multi-modal surface transportation issues, educating a diverse array of current practitioners and future leaders in the transportation field, and encouraging implementation of relevant research results. 